\title{
Görsel İletişim Aracı Olarak İnfografiklerin Öğrenme Süreçlerinde Kullanımı: Dijital Yerliler İçin Kuramsal Bir Çerçeve
}

- Tülay GÖRÜ

\section{DOĞAN}

Dr. Öğr. Üyesi Alanya HEP

Üniversitesi

tgorudogan@alanyahep.edu.tr ORCID ID: 000-0002- 94428926

- T. Volkan YÜZER

Prof. Dr. Anadolu

Üniversitesi

vyuzer@anadolu.edu.tr

ORCID ID: 0000-0002-83166115

\section{ÖZET}

Bu araştırmada, dijital yerlilerin ögrrenme süreçlerinde görsel iletişim aracı olarak infografiklerin nasıl kullanılabileceğine ilişkin önerilerin sunulduğu kuramsal bir çerçevenin gelişstirilmesi amaçlanmıştır. Bu amaçla, dijital yerlilerin öğrenme süreçlerinde infografiklerin nasil kullanilabileceği sorusu, araştırmanın ana sorusu olarak belirlenmiştir. Nitel bir baklş açısıyla desenlenen bu araştırmada, araştırma modeli olarak döküman incelemesi yöntemi tercih edilmiştir. Bu bağlamda, araştırma kapsamında Tapscott (2009) tarafindan tanımlanan dijital yerlilerin özellikleri (hiz, bütünlük, eğlence, yenilik, işbirliği, inceleme ve kişiselleştirme, özgürlük) ile Smiciklas (2012) tarafindan infografik kavramının üstün yönlerini ifade etmede kullanilan ilkelerden (özlük, kavrama, eylem ve katılım) oluşan bir kuramsal çerçeve geliştirilmiştir. Sonuç olarak, araştırma kapsamında geliştirilen kuramsal çerçevenin, dijital yerliler ve infografik konularında araştırma yapmak isteyen kurum/kuruluşlara, araştırmacılara ve ögrenenlere yol gösterici nitelikte olduğu söylenebilir. Buna ek olarak, gelecekte yapılacak çalışmalar için benzer konunun farklı teknolojilerle ve farklı gruplarla geniş kapsamda çalışılması, araştırma kapsamında sunulan kuramsal çerçevenin geliştirilerek uygulamaya dayalı bir araştırmaya dönüştürülmesi araştırmanın önerileri arasında yer almaktadir.

Anahtar Sözcükler: Dijital yerliler, dijital iletişim, infografik, kuramsal çerçeve, görsel iletişim tasarımı.

Geliş Tarihi $\quad 02.08 .2020$

Kabul Tarihi

07.12 .2020

Yayın Tarihi

15.01 .2021 


\section{Use of Infographics as a Visual Communication Tool in the Learning Processes: A Theoretical Framework for Digital Natives}

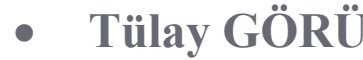
DOĞAN

Asst. Prof. Dr. Alanya HEP Üniversitesi

tgorudogan@alanyahep.edu.tr ORCID ID: 000-0002- 94428926

\section{- T. Volkan YÜZER}

Prof. Dr. Anadolu

Üniversitesi

vyuzer@anadolu.edu.tr ORCID ID: 0000-0002-83166115

\begin{abstract}
This study aims to develop a theoretical framework to suggest how infographics could be used in digital natives' learning processes. For this purpose, the main question of the research is set as how infographics can be used in digital natives' learning processes? This study was designed with a qualitative research perspective, the document analysis method was preferred as the research model. In this context, the basis of the theoretical framework presented within the scope of the research is derived from the principles (freedom, corporate integrity, openness, entertainment, play, collaboration, relationship, and speed) used to define the characteristics of the Digital Natives by Tapscott (2009) and Smiciklas (2012), which expresses the superior aspects of the concept (brevity, insight, action and, engagement) of infographics. As a result, the theoretical framework developed within the scope of the research can guide the institutions/organizations, researchers, and learners willing to do research on digital natives and infographics. In addition, the researchers suggest that a similar subject could be investigated with different technologies and groups for future studies, and the theoretical framework presented within the scope of the research can be developed and transformed into application-based research.
\end{abstract}

Keywords: Digital natives, digital communication, infographics, theoretical framework, and visual communication design. 


\section{GİRIŞ}

İlk kez 2001 yılında Marc Prensky tarafından alanyazına kazandırılan dijital yerli kavramı (Kirschner \& Bruyckere, 2017; Ng, 2012), 1990'lardan sonra doğan ve anadili bilgisayarların, video oyunlarının ve internetin dijital dili olan bireyleri (Prensky, 2001a) tanımlamak için kullanılmaktadır. Günlük yaşantılarının önemli bir bölümünü ekran karşısında (Tapscott, 2009, s. 3) ya da çevrimiçi olarak geçiren dijital yerliler, internetin, hayatlarının doğal bir bileşeni olduğuna inanmaktadır (Dingli \& Seychell, 2015, s. 9). Paralel süreçlerde çoklu-görev (multitasking) yürütebilme becerisine (Prensky, 2001a; Palfrey \& Gasser, 2008; Tapscott, 2009; Kirschner \& Merrie n̈boer, 2013) sahip olan dijital yerliler, iletişim, öğrenme, sosyalleşme, vb. pek çok açıdan, kendilerinden önceki nesilden farklılık göstermektedir (Helsper \& Eynon, 2010; Prensky, 2001b; Palfrey \& Gasser, 2008).

Günümüzde, grafikler, şekiller, diyagramlar, vb. görsellerle dolu bir dünyada yaşamlarını sürdüren dijital yerliler, yavaş tempolu ortamlarda kolaylıkla sıkılabilmekte, yoğun miktarda dijital veri akışına maruz kaldıklarında öğrenmeye ilişkin ilgi ve motivasyonlarını kolaylıkla kaybedebilmektedirler (Thompson, 2013). Benzer şekilde, Tapscott (2009), Gates Vakfi tarafından 2006 yılında yayınlanan bir rapora göre her on öğrenciden yedisinin motive olamamaları gerekçesiyle ders bıraktıklarını ve ders bırakanların neredeyse yarısının bıraktıkları dersleri ya sıkıcı bulduklarını ya da yeterince ilginç bulmadıklarını belirtmiştir. $\mathrm{Bu}$ durum, dijital yerlilerin öğrenme deneyimlerinin, içinde yaşadıkları gerçek dünyayla ilgili olmasını, ilginç ve hatta eğlenceli olmasını istediklerini göstermektedir. Bu bağlamda, öğrenme süreçlerinde hız, yenilik, özgürlük, vb. özelliklerin yanı sira metin yerine grafikleri tercih eden (Tapscott, 2009; Thompson, 2013) dijital yerlilerin, öğrenme süreçlerinde infografiklerden yararlanılması etkili bir yöntem olarak düşünülebilir. Karmaşık verilerinin görsel bir temsili olarak tanımlanabilen infografikler (Krum, 2014, s. 6), öğrenme süreçlerinde kullanılmak üzere umut verici bir teknik (Alrwele, 2017, s. 105) olarak gösterilmektedir. Aynı zamanda, dijital çağda bilgi aktarımı için en verimli içerik biçimlerinden biri olarak da ifade edilebilen infografiklerin (Smiciklas, 2012, s. 11), dijital yerlilerle etkili bir iletişimin gerçekleştirilmesi konusunda (Yuvaraj, 2017, s. 9) öğrenme süreçlerine katk1 sağlayabileceği düşünülmektedir.

$\mathrm{Bu}$ araştırmada, dijital yerlilerin öğrenme süreçlerinde, görsel iletişim aracı olarak infografiklerin nasıl kullanılabileceğine ilişkin kuramsal bir çerçevenin geliştirilmesi 
amaçlanmıştır. Bu bağlamda, dijital yerlilerin öğrenme süreçlerinde infografiklerin nasıl kullanılabileceği sorusu, araştırmanın temel sorusu olarak belirlenmiştir. $\mathrm{Bu}$ nedenle, araştırmanın, dijital yerliler ve infografik kavramına ilişkin ulusal ve uluslararası alanyazında yer alan çalışmaların ayrıntılı bir biçimde incelenmesiyle kuramsal bir çerçeve sunması ve ileride yapılacak uygulamaya dayalı araştırmalar için bir yapı önermesi bakımından önemli olduğu düşünülmektedir.

\section{DİJITAL YERLI KAVRAMI}

\subsection{Dijital Yerlilerin Tanımı ve Özellikleri}

Dijital yerli kavramı ile ilgili çalışmalar, 1990'ların sonlarında ve 2000'lerin başında şekillenmeye başlamış olmakla birlikte (Smith, 2012, s. 2), ilk kez 2001 yılında Marc Prensky tarafından alanyazına kazandırılmıştır (Kirschner \& Bruyckere, 2017; Ng, 2012). Yeni nesil öğrenenlerin özelliklerini tanımak ve onlara uyum sağlamak amacıyla yapılmış çalışmalara gereksinim duyulması ile gündeme gelen dijital yerli kavramı, alanyazında farklı tanımlamalarla da karşımıza çıkmaktadır. Alanyazında, yeni nesli ifade etmede kullanılan söz konusu kavramlar Tablo 1'de sunulmaktadır.

Tablo 1. Alanyazında, yeni nesli tanımlamada kullanılan kavramlar

\begin{tabular}{ll}
\hline Kavram & Yazar \\
\hline Dijital Yerli & Prensky (2001a; 2001b), Williams, Crittenden, Keo ve \\
Net Nesli & Tapscorty (2012), Leppisaari ve Lee (2012). \\
Google Nesli & Helsper ve Eynon (2010) \\
Milenyumlular & Howe ve Strauss (2000) \\
Siber çocuklar & Holloway ve Valentine (2002) \\
\hline
\end{tabular}

Prensky (2001a, s. 1) dijital yerlileri, 1990'lardan sonra doğan ve anadili bilgisayarların, video oyunlarının ve internetin dijital dili olan bireyler olarak tanımlamaktadır. Palfrey \& Gasser (2008) ise dijital yerlileri, ağa bağlı dijital teknolojilere erişimi olan ve bu teknolojileri kullanma becerisine sahip, 1980'den sonra doğan bireyler olarak ifade etmektedir. Prensky'e (2001a) göre, dijital yerliler, hayatlarının tamamını 
bilgisayarlarla, video oyunlarıyla, dijital müzik çalarlarla, videolarla, cep telefonları ve dijital çağın getirdiği diğer tüm araçlar ile çevrilmiş olarak geçirmektedirler. Günün önemli bir bölümünü televizyon, tablet, bilgisayar oyun konsolu, vb. ekran karışında geçiren bu bireyler için screenagers terimi türetilmiştir (Tapscott, 2009, s. 3). Zamanının büyük bir bölümünü çevrimiçi olarak geçiren dijital yerliler, internetin, hayatlarının doğal bir bileşeni olduğuna inanmaktadır (Dingli \& Seychell, 2015, s. 9). İşyeri de dâhil olmak üzere, her firsatta sosyal medyada (Facebook, Instagram, Twitter, vb.) görünmektedirler (Tapscott, 2009, s. 9). Bu durumun, günlük yaşamlarında dijital yerlilerin, sürekli olarak dijital bilgi akışına maruz kalmalarına neden olduğu ifade edilebilir.

Dijital yerlilere ilişkin, alanyazında sıklıkla karşılaşılan özelliklerden biri de paralel süreçlerde çoklu-görev (multitasking) yürütebilme becerisidir (Prensky, 2001a; Palfrey \& Gasser, 2008; Tapscott, 2009; Kirschner \& Merrie n̈boer, 2013). Bu özellik, aynı anda birden fazla etkinlikle meşgul olma olarak ifade edilebilmektedir. Telefonda konuşuyorken epostalarını kontrol etme, anlık mesajlaşma, webde gezinme, fotoğraf çekme, vb. örnek olarak gösterilebilir. Dingli ve Seychel (2015), bu bireylerin, dijital dünyayı farklı bir gözle algıladıklarını belirtmektedir. Kendilerinden önceki nesillerde yenilik olarak atfedilen şeylerin, dijital yerliler için sıradan olduğu, hatta hayatlarının ayrılmaz bir parçası olduğu söylenebilmektedir. Kendilerinden önceki nesil webde içerik tüketirken, onlar sürekli olarak çevrimiçi içerik üretmekte ve/veya değiştirmektedirler. Benzer şekilde, kendilerinden önceki nesil, yeni bir cihaz satın aldıktan sonra kullanma kılavuzunu incelerken, dijital yerliler yeni bir cihazı satın alıp doğrudan kullanabilmektedirler. Tapscott (2009, s. 10), dijital yerlilerin, dijital araçlar konusunda akıllara durgunluk veren bir yetenekleri olduğunu, adeta teknolojiyle ziyafet çektiklerini ifade etmektedir. Kısacası, dijital yerlilerin, teknolojiyi nasıl etkili bir biçimde kullanabilecekleri konusunda yeni düşünme yolları geliştirebildikleri ve teknolojiyi başka bir şeyle karşılaştırarak tanımlamaya gereksinim duymadıkları söylenebilmektedir.

Palfrey ve Gasser (2008), kendilerinden önceki neslin aksine, dijital yerlilerin birbirleriyle farklı bir biçimde tanışmakta, çalışmakta ve etkileşmekte olduğunu ifade etmektedir. Benzer şekilde, Thomas (2011, s. 4), dijital yerlileri kendilerinden önceki nesilden ayıran üç varsayımı şu şekilde sıralamaktadır:

1) dijital teknolojiler karşısında farklı bir dil konuşmaktadırlar, 
2) farklı bir şekilde öğrenmektedirler,

3) teknolojiyi içeren yeni bir öğrenme ve öğretme yöntemini tercih etmektedirler.

Diğer yandan, Helsper ve Eynon (2010, s. 506), dijital yerlilerin özelliklerini (1) yaş, (2) deneyim ve (3) kullanım genişliği açısından şu şekilde açıklamaktadır:
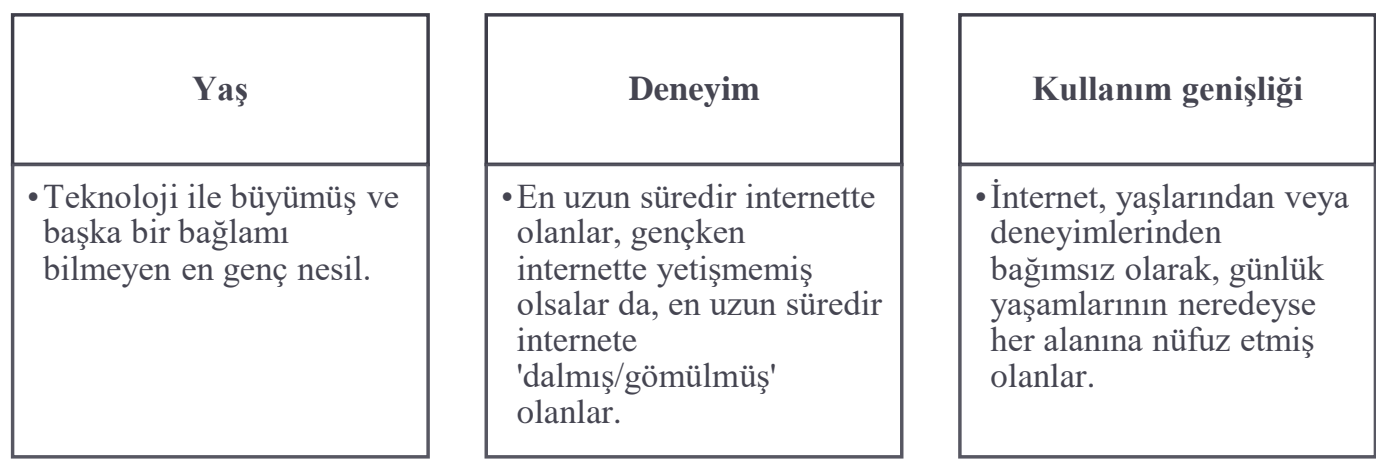

Şekil 1. Dijital yerlilerin özellikleri (Helsper \& Eynon, 2010).

Yukarıdaki ifadelere ek olarak, Tapscott (2009), dijital yerlileri aşağıda yer alan sekiz özellik ile tanımlamaktadır:

1. Özgürlük: Dijital yerliler, seçim özgürlüğünden ifade özgürlüğüne kadar yaptıkları her şeyde özgürlük istemektedirler. Önceki nesiller, satış kanallarının, ürün türlerinin ve markaların çoğalması karşısında bunalmış hissederken, dijital yerliler bu durumu kabul etmekte ve karmaşayı ortadan kaldırmak ve ihtiyaçlarına uygun pazarlama mesajını bulmak için teknolojiden yararlanmaktadırlar. Kısacası, dijital yerliler, kendi yollarını kullanma ve kendilerini ifade etme özgürlüğünü aramaktadırlar.

2. Kişiselleştirme: Dijital yerliler, çevrelerindeki medya dünyasını (masaüstü, web sitesi, zil sesi, tanıtıc1, ekran koruyucu, haber kaynakları, eğlence, vb.) değiştirebilmektedirler. İstedikleri ortamı, ne zaman istediklerini ve nasıl istediklerine göre şekillendirebilmektedirler. Dijital yerliler, yalnızca webe erişmekle kalmamakta, aynı zamanda çevrimiçi içerik oluşturarak webi istedikleri gibi yeniden oluşturabilmektedirler. 
3. İnceleme: Dijital yerliler için şeffaflık, yani kurumlar, paydaşlar, şirketler, vb. hakkında ilgili bilgilere erişim son derece doğal görünmektedir. Çevrimiçi katılımları yüksektir. Hedef kitlesi dijital yerliler olan işletmeler, ürünlerinin, tanıtım çabalarının ve kurumsal uygulamalarının yoğun bir şekilde incelenecek olduğunun farkında olmalı ve bu durumu memnuniyetle karşılamalıdır.

4. Bütünlük: Dijital yerliler, ne satın alacakları, nerede çalışacakları, vb. konulara karar verirken kurumsal bütünlük ve açıklık (openness) aramaktadırlar.

5. İşbirliği: Dijital yerlilerin, işbirliği ve ilişki odaklı olduğunu söylemek mümkündür. Sosyal ağlarda işbirliği yapabilmekte, çok kullanıcılı video oyunları oynayabilmekte ve birbirleri ile okul, iş veya yalnızca eğlence amaçlı veriler paylaşabilmektedirler.

6. Eğlence: Dijital yerliler, işyerinde, eğitimde ve sosyal yaşamlarında eğlence ve oyun odaklıdırlar. Video oyunlarındaki deneyimlerinden hareketle, bir hedefe ulaşmak için her zaman birden fazla yol olduğunun farkındadırlar.

7. Hız: Dijital yerliler, yalnızca video oyunlarında değil, yaşamlarının her anında hıza gereksinim duymaktadırlar. Hızın, bilgi akışını biçimlendirdiği bir dünyada, arkadaşlar, meslektaşlar vb. ile olan iletişim her zamankinden daha hızlı gerçekleşmektedir. Bilgiye çok hızlı bir biçimde erişmeye alışkın olan dijital yerliler (Helsper \& Eynon, 2010), mesajlarına aynı hızda yanıt almak istemektedirler.

8. Yenilik: Dijital yerliler, yeni bir teknolojiyi, bir önceki teknoloji artık eski olduğu için değil, yeni olanın çok daha iyi (cool) olduğunu düşündüğü için istemektedirler. Çalışabilecekleri yenilikçi şirketler, kurum ve/veya kuruluşlar aramakta ve işbirliği yapmak, öğrenmek, çalışmak ve kendilerini eğlendirmek için yenilikçi yollar denemektedirler.

\subsection{Dijital Yerli Kavramına Yönelik Eleștiriler}

Yukarıda sıralanan özelliklere ek olarak, alanyazında dijital yerli kavramına yönelik eleştirilere de rastlanmaktadır (Tapscott, 2009, s. 3). Dijital yerli kavramına ilişkin söz konusu eleştirilerin odak noktaları şu şekilde özetlenebilmektedir ( $\mathrm{Ng}, 2012$, s. 1065): 
1) 1980 ve sonrasında doğanların dijital yerliler olduğu söylemine yönelik eleştiriler: Dijital yerlileri tanımlarken, göz önünde bulundurulması gereken faktörün yaş veya doğum yılı değil, teknolojinin mevcudiyeti, kullanım genişliği, önceki deneyim, öz-yeterlik ve eğitim gibi daha önemli unsurlar olduğu yönünde yapılan eleştiriler.

2) Dijital yerlilerin teknolojiye ulaşılabilirliği ve kullanımına yönelik eleştiriler: Dijital yerlilerin teknoloji kullanımlarının eğitim durumlarına, teknolojiye sahip olma durumlarına, vb. farklılık gösterebileceği ve çoğu kişinin söz konusu teknolojileri kullanacak beceri ve yetkinliklerden yoksun olduğu yönünde yapılan eleştiriler.

3) Dijital yerlilerin teknoloji ile çevrili bir dünyada büyüdükleri için, beyinlerinin önceki nesillerden farklı olarak geliştiği söylemine yönelik eleştiriler: Dijital yerlilerin beyin yapısının, interneti ve diğer teknolojileri sık kullanmaları nedeniyle farklı olduğunu gösteren ampirik bir kanıt bulunmadığı yönünde yapılan eleştiriler.

Yukarıdaki eleştirilere ek olarak, Bennett, Maton ve Kervin (2008), dijital yerlilerin teknoloji ile ilişkileri üzerine yapılan araştırmalardan ortaya çıkan tanımın, dijital yerli kavramının önerdiği özelliklerden çok daha karmaşık olduğunu ifade etmektedirler. Dijital yerli olarak adlandırılan genç neslin, her ne kadar hayatlarında yer etmiş olsa da, teknoloji kullanımı ve buna yönelik becerilerin tekdüze olmadığı savunulmaktadır. Aynı zamanda, Benett, Maton ve Kervin (2008, s. 779) dijital yerlilerin, kendinden önceki nesillerin sahip olduğundan farklı bir öğrenme stiline veya çoklu-görev becerisine sahip olduklarına ilişkin kesin bir kanıt olmadığı yönünde eleştiri getirmektedirler. Benzer şekilde, Kirschner ve Bruyckere (2017), dijital yerli kavramına, bu nesildeki bireylerin iddia edildiği gibi çoklu görev yapabilme yeteneğinin bulunmadığına ilişkin eleştiride bulunmaktadırlar. Diğer yandan, Smith (2012), aşağıda yer alan konulara yönelik belirsizlikler nedeniyle dijital yerli kavramına yöneltilen eleştirileri şu şekilde sıralamaktadır:

- Öğrenen çeşitliliği ve karmaşıklığı,

- Sosyo-ekonomik durum ve dijital bölünme,

- Teknoloji kullanma/çevrimiçi olma nedenlerinin farklılığı. 
Bununla birlikte, Prensky (2011, s. 17), dijital yerli kavramına ilişkin kendisine yöneltilen eleștirilerin bir kısmını uygun bulurken bir kısmını da uygun bulmadığını ifade etmektedir. Özellikle, dijital yerlilerden bir önceki nesli tanımlamak için kullanılan dijital göçmen (digital immigrant) metaforunun, bir araya gelmekten ve karş1lıklı öğrenmekten ziyade bölünmeye ve ayrıma odaklandığın, bu kullanımın yanlış anlatımlara neden olabileceğini kabul etmektedir. Ancak, herhangi birinin belirli bir tarihten sonra doğması ve bu nedenle kayıtsız olarak dijital yerli olarak kabul edilmesinin ve tüm bilgisayar sistemleri hakkında her şeyi bildiklerinin varsayılması yönündeki eleştirileri de uygun bulmamaktadır. Söz konusu kavramın, daha çok kültür ile ilgili olduğunu vurgulayan Prensky (2011, s. 17), bir oyuncak gibi dijital teknoloji ile büyüyen dijital yerlilerin teknoloji kullanımı ile dijital teknolojileri kullanmamış olan neslin birbirinden farklılık göstermesinin beklenebileceğini ifade etmektedir.

Sonuç olarak, Jones'un (2011) da belirttiği gibi, dijital teknolojilerle zenginleştirilmiş bir ortamın varlığının, bu yeni teknolojilere aktif katılanlar ve katılmayanlar arasında kuşaksal bir farklılığa yol açtığı normal karşılanabilir. Benzer şekilde, Levy’e (2011) göre, bilgi iletişim teknolojileri ve dijital medyanın, küçük çocukların öğrenme, oynama, çalışma ve sosyalleşme biçimleri üzerinde büyük bir etkisi olduğu konusunda şüphe bulunmamaktadır. Dolayısıyla, her dijital yerli ögrenen olmamakla birlikte, bu çalışma kapsamında, dijital yerli özelliklerini gösteren öğrenenlere ilişkin değerlendirmelerde bulunulmuştur. Bu bağlamda, dijital teknolojilerle iç içe büyüyen bireyleri ifade etmesi bakımından çalışma kapsamında dijital yerli olarak ifade edilen bireylere ilişkin öğrenme ve iletişim etkinliklerinin tasarlanması, yürütülmesi, vb. konularda yapılacak araştırmaların, alanyazına değer kazandıracağı düşünülmektedir.

\subsection{Dijital Yerliler ve Öğrenme}

Palfrey ve Gasser (2008), dijital teknolojilerin, öğrenenlerin yaşamlarının her alanında bilgi toplama ve işleme biçimini değiştirmesi nedeniyle, son otuz yılda öğrenmede de değişim ve dönüşüm meydana getirdiğini belirtmektedirler. $\mathrm{Bu}$ teknolojilerle biçimlenen genç nesillerin iletişim, sosyalleşme ve öğrenme alışkanlıkları ebeveynlerinden büyük ölçüde farklıl1k göstermektedir (Helsper \& Eynon, 2010; Prensky, 2001b). Örneğin, dijital yerliler için araştırma sözcüğünün, kütüphaneye yapılan bir yolculuk eylemi yerine, Google aramas1 
yapma, bir viki topluluğunda gezinme veya çevrimiçi bir arkadașına sorma eylemi anlamına gelmesi olasılığı daha yüksek (Palfrey \& Gasser, 2008) olduğu ifade edilebilir.

Tapscott (2009), dijital yerlilerin öğrenme sürecine ilişkin sahip oldukları özelliklerin, özgürlük, hız, yenilik, vb. özelliklerle uyum gösterdiğini belirtmektedir. Tapscott'a (2009) göre, dijital yerliler, gerekesinim duydukları bilgiye erişmede bağımsız olma konusunda güçlü bir eğilim göstermektedirler. Doğaları gereği, dijital yerliler iyi bir araştırmacıdırlar (Downes \& Bishop, 2012) ve webde bulunan sayısız fırsatı keşfetmekten keyif almaktadırlar (Thomas, 2011, s. 7). Her ne kadar, çevreleri çok sayıda bilgi ile çevrilse de, maruz kaldıkları bu bilgileri ve kimlikleri sürekli olarak doğrulama gerekliliğine karşı duyarlı oldukları söylenebilmektedir. Dijital yerlilerin öğrenmeye ilişkin diğer özellikleri ise Thompson'dan (2013) uyarlanan Tablo 2'de gösterilmektedir.

Tablo 2. Dijital yerlilerin öğrenme özellikleri (Thompson, 2013'den uyarlanmıştır)

\begin{tabular}{|c|c|c|}
\hline ÖZELLIK & POTANSIYYEL FAYDA & POTANSIYYEL RISSK \\
\hline $\begin{array}{l}\text { Hız tutkusu, ağır hareket } \\
\text { edilen ortamlara karşı } \\
\text { tahammülsüzlük }\end{array}$ & $\begin{array}{l}\text { Metinleri tarama ve bilgileri hılı } \\
\text { bir şekilde işleyebilme becerisi }\end{array}$ & $\begin{array}{l}\text { Derin okuma, yansıtma ve soyut } \\
\text { düşünme becerisinin gelişimini } \\
\text { engelleme }\end{array}$ \\
\hline $\begin{array}{l}\text { Çoklu-görev yapma arzusu } \\
\text { veya algisı }\end{array}$ & $\begin{array}{l}\text { Can sıkıntısını önleme: dijital } \\
\text { yerliler ihtiyaç duyulduğunda çoklu } \\
\text { görevlerle başa çıkabilirler }\end{array}$ & $\begin{array}{l}\text { Hafizaya müdahale eder, çalışma } \\
\text { süresinin verimsizleşmesine, } \\
\text { notların düşmesine ve zihinsel } \\
\text { bitkinliğe neden olur }\end{array}$ \\
\hline $\begin{array}{l}\text { Metin yerine görselleri tercih } \\
\text { etme }\end{array}$ & $\begin{array}{l}\text { Görsel-uzamsal becerileri } \\
\text { geliştirebilme }\end{array}$ & $\begin{array}{l}\text { Görsel beceriler derin ve yansıtıcı } \\
\text { okuma yeteneğinin azalması } \\
\text { pahasına kazanılabilir }\end{array}$ \\
\hline $\begin{array}{l}\text { Bilgileri doğrusal olmayan } \\
\text { yollarla işlemeye eğilim }\end{array}$ & $\begin{array}{l}\text { Çoklu bakış açıları iyi } \\
\text { yapılandırılmamış alanların } \\
\text { doğasında bulunan karmaşıklığın } \\
\text { daha iyi anlaşılması için potansiyeli } \\
\text { artırabilir }\end{array}$ & $\begin{array}{l}\text { Doğrusal okumanın en verimli } \\
\text { strateji olduğu durumlarda bile } \\
\text { doğrusal biçimde okuma } \\
\text { yeteneğinin kaybolmasına neden } \\
\text { olabilir }\end{array}$ \\
\hline $\begin{array}{l}\text { İşbirliği ve sürekli bağlantıda } \\
\text { olmayı tercih etme }\end{array}$ & $\begin{array}{l}\text { Öğrenmeyi iyileştirmek için kişisel } \\
\text { çevrimiçi ağları kullanma, } \\
\text { öğrenmeyle ilişkilendirebilmek için } \\
\text { Vikipedi gibi özgün projelere katkı } \\
\text { sağlama }\end{array}$ & $\begin{array}{l}\text { Öğrenmenin azalması pahasına } \\
\text { sosyalleşmeye aşırı odaklanma }\end{array}$ \\
\hline $\begin{array}{l}\text { Okuma veya dinleme yerine } \\
\text { etkinlik yoluyla öğrenmeyi } \\
\text { tercih etme }\end{array}$ & $\begin{array}{l}\text { Öğretilmesi için beklemek yerine } \\
\text { bir şeyleri kendi kendine çözebilme }\end{array}$ & $\begin{array}{l}\text { Rehber eşliğinde gerçekleşen } \\
\text { öğretime karşı sabırsıllık, esas } \\
\text { içeriğin öğrenilmesini } \\
\text { engelleyebilir }\end{array}$ \\
\hline $\begin{array}{l}\text { İş ve eğlence zamanlarını } \\
\text { karıştırma; gayret gerektiren } \\
\text { uğraşlar için boş zamanı } \\
\text { kullanma }\end{array}$ & $\begin{array}{l}\text { Bilişsel oyunbazlıkla öğrenmeyi } \\
\text { zenginleştirebilme }\end{array}$ & $\begin{array}{l}\text { Öğretmenin onları eğlendireceği } \\
\text { beklentisi, kişisel öğrenmeyi } \\
\text { olumsuz etkileyebilir }\end{array}$ \\
\hline $\begin{array}{l}\text { Oyunlarda olduğu gibi } \\
\text { gösterilen çaba için anında geri }\end{array}$ & $\begin{array}{l}\text { Anında geri bildirim sağlanan } \\
\text { ortamlarda öğrenmeye ilişkin }\end{array}$ & $\begin{array}{l}\text { Kısa vadeli/geçici sıkıntılar } \\
\text { karşısında kararlı biçimde devam }\end{array}$ \\
\hline
\end{tabular}




\begin{tabular}{lll}
\hline bildirim ve kazanç beklentisi & motivasyonunu artırabilme & $\begin{array}{l}\text { edememe, öğrenmeyi olumsuz } \\
\text { etkileyebilir }\end{array}$ \\
\hline $\begin{array}{l}\text { Oyunlarda, gerçekçi TV ve } \\
\text { filmlerde olduğu gibi olağan } \\
\text { üstü durumlara yönelme }\end{array}$ & $\begin{array}{l}\text { Kurgu/hayal gücü bağlamının } \\
\text { bulunduğu öğrenme ortamında } \\
\text { öğrenme motivasyonunun artma } \\
\text { potansiyeli }\end{array}$ & $\begin{array}{l}\text { Tüm öğrenme biçimleri } \\
\text { kurgu/hayal gücü üzerinden } \\
\text { öğrenemeye dayanmadığı için }\end{array}$ \\
\hline $\begin{array}{l}\text { Teknolojinin tabiatının bir } \\
\text { parçası olduğu beklentisi; } \\
\text { teknolojiden yoksun } \\
\text { ortamlarda zorluk çekme }\end{array}$ & $\begin{array}{l}\text { Teknolojinin pedagojik } \\
\text { kullanımının, kavramsal anlayışı verimsizlik yaşanabilir }\end{array}$ \\
\hline
\end{tabular}

Tablo 2'den de anlaşılacağı gibi, dijital yerlilere ilişkin öğrenme özelliklerinden biri de metin yerine görselleri tercih etmeleridir (Thompson, 2013, s. 14). Benzer şekilde, Prensky (2001a) ve Tapscott (2009), dijital yerlilerin öğrenme süreçlerinde metin yerine grafikleri tercih ettiğini belirtmektedir. Tapscott (2009, s. 106), dijitalleşen dünyada, dijital yerlilerin resim, grafik ve simgeler gibi görüntülerin nasıl okunacağını öğrendiklerini öne sürmektedir. California Eyalet Üniversitesi'nde (Hayward) yapılan bir araştırmada, öğrenenler ödevleri için uzun metin yönergelerini göz ardı etmekteyken, ders yürütücüleri öğretme yöntemlerini değiştirerek görsel imgelerden yararlanmışlardır. Araştırma, öğrenenlerin akademik başarılarının \%11 ila \%16 arasında artış göstermesiyle sonuçlanmıştır. Dolayısıyla, bu araştırma kapsamında, dijital yerlilerin öğrenme süreçlerinde görsel bir iletişim aracı olarak infografiklerin kullanımı tercih edilmiştir. Bu doğrultuda, bir sonraki alt başlıkta öncelikli olarak infografik kavramı ayrıntılı bir biçimde açıklanmakta ve infografiklerin dijital yerlilerin öğrenme süreçlerinde nasıl kullanılabileceğine ilişkin bir bakış açısı sunulmaktadır.

\section{INNFOGRAFIK KAVRAMI}

İnfografik, bilinen en eski tanımıyla verinin (info) görsel bir temsili (grafik) olarak ifade edilebiliyorken, günümüzde artık bu tanım veri görselleştirmesinden çok daha fazlasını ifade etmektedir (Krum, 2014, s. 6). Krum (2014), infografik kavramının, veri görselleştirmelerini, illüstrasyonları, metinleri ve görüntüleri eksiksiz bir hikâye oluşturacak şekilde daha büyük bir grafik tasarım sürecini içeren yeni bir formatta geliştiğini ifade etmektedir. Smiciklas (2012, s. 3) ise infografiğgi, bir kitleye hızlı bir şekilde tüketilebilecek ve kolayca anlaşılabilecek bir şekilde karmaşık bilgileri aktarmaya çalışan verilerin veya fikirlerin görselleştirilmesi olarak tanımlamaktadır. Başlangıçta, gazete ve dergiler için grafik üretiminde kullanılan bir terim olan infografik, (Dyjur \& Li, 2015, s. 65) bireylerin ve 
kuruluşların mesajlarını dinleyicilere özlü bir şekilde iletmelerine yardımcı olan ve verileri tasarımla harmanlayan bir resim türü olarak da ifade edilebilmektedir. Bir infografik geliştirme ve yayınlama sürecine veri görselleştirme, bilgi tasarımı veya bilgi mimarisi denilmektedir (Smiciklas, 2012, s. 3). Bu süreci açıklayan görsel Şekil 2'de yer almaktadır:

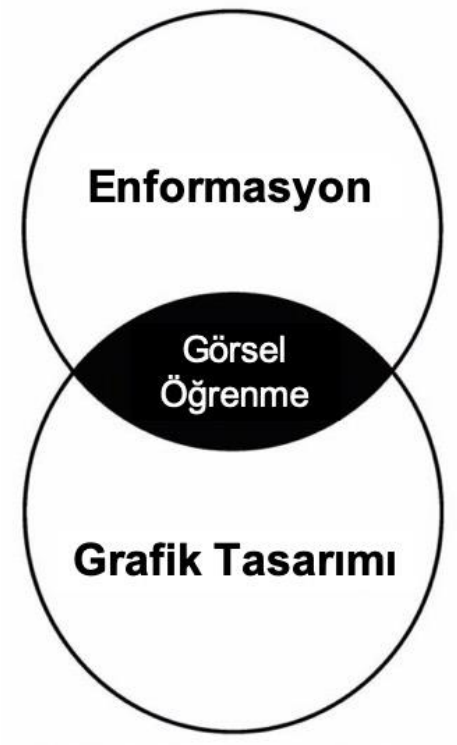

Şekil 2. Bir infografiğin anatomik yapısı (Smiciklas, 2012, s.4'ten uyarlanmıştır).

Şekil 2'den de anlaşılabileceği gibi, bir infografiğin, enformasyonun (information) bir grafik tasarım süreci ile birlikte, görsel öğrenmenin gerçekleştirilmesine katkı sağlaması amacı ile üretilen bir yapı olarak değerlendirilmesi mümkündür. Çaydere (2016, s. 94), grafik tasarımını, iki iletişim unsuru olan resim ve yazının birlikte kullanıldığı bir iletişim türü olarak tanımlamaktadır. Frascara $(2004$, s. 4) ise grafik tasarımı sürecinin bir yöntem (tasarım); bir amaç (iletişim); ve bir ortam (vizyon) içermesi nedeniyle bu kavramın görsel iletişim tasarımı olarak kullanımının daha uygun olacağı görüşündedir. Dolayısıyla, grafik tasarımı ve görsel iletişim tasarımı kavramları arasındaki ilişki, görsel bir iletişim süreci aracılığıyla, insanların bilgi, tutum ve davranışlarını etkilemek (Frascara, 2004, s. 12) olarak açıklanabilmektedir.

Bu bağlamda, Nuhoğlu-Kibar ve Akkoyunlu (2018, s. 99), tasarımı doğası gereği infografiklerin, aktif olarak bir bilginin anlamlandırılması ve oluşturulması sürecini 
gerektirdiğini ifade etmektedirler. İstatistikleri veya araştırma bulgularını iletmenin en etkili yolu olarak görülen infografiklerin yararlarına ilişkin diğer ilkeler ise şu şekilde s1ralanabilmektedir (Smiciklas, 2012, s. 25):

- Özlük: İnfografikler özlüdür, bir kitlenin büyük miktardaki veriyi hızlı bir şekilde anlamasına yardım eder.

- Kavrama: Veri görselleştirme ile ilgili kitlenin, sayıların içindeki öyküyü görmesine katk1 sağlar.

- Eylem: İstatistiksel infografikler, hızlı karar verebilme ve harekete geçebilme konusunda rehberlik eder.

- Katılım: Veri görselleştirme ile bir kurum ve/veya kuruluşta çalışanların ilgisinin daha fazla çekilmesine ve ilgili çalışanların düşüncelerini ifade etme, problem çözme vb. süreçlere aktif bir biçimde katılmasına destek olur.

Benzer şekilde, Smiciklas (2012, s. 94), bir infografik tasarım aşamasını, gazeteciler tarafindan kullanılan $5 \mathrm{~N} 1 \mathrm{~K}$ sürecine benzeterek bu süreçte, Kim, $\mathrm{Ne}, \mathrm{Ne}$ zaman, Nerede, Neden ve Nasıl sorularının yanıtlanması gerektiğini belirtmiştir. Görselleştirmenin tasarım aşamasında gözlemlerin, fikirlerin ve verilerin harmanlanmasında söz konusu sürecin kullanışlı bir kaynak haline gelmesi beklenmektedir. Tablo 3'te, bir infografiğin tasarım sürecinde hangi aşamada, hangi soruların yanıtlanması gerektiği ayrıntılı bir biçimde açıklanmaktadır (Smiciklas, 2012):

Tablo 3. Infografik tasarım aşaması (Smiciklas, 2012'den uyarlanmıştır)

\begin{tabular}{lll}
\hline AŞAMA & SORU & AÇIKLAMA \\
\hline \multirow{2}{*}{ KIM? } & Hedef kitle kimdir? & $\begin{array}{l}\text { İfografiğin kimin için tasarlandığ1 sorusunun yanıtı aranır. } \\
\text { Sektörün kültürü veya üretilen içeriği tüketecek kişilerin genel } \\
\text { yapısı, görselleştirilmesi gereken bilgilerin türünü belirler. }\end{array}$ \\
\hline & Amaç nedir? & $\begin{array}{l}\text { İnfografiğin amacını belirlemek, amaca yönelik uygun fikirlerin } \\
\text { sentezlenmesine yardımcı olur. }\end{array}$ \\
\cline { 2 - 3 } NE? & İletilecek mesaj nedir? & $\begin{array}{l}\text { Düşüncelerin filtrelenmesi aşaması, hedef kitle için en ilgili ve } \\
\text { önemli mesajın seçilmesine, yaratıc1 yönün kristalize edilmesine } \\
\text { katkı sağlar. }\end{array}$ \\
\cline { 2 - 3 } & $\begin{array}{l}\text { Başka hangi bilgilere } \\
\text { gereksinim } \\
\text { duyulmaktadır? }\end{array}$ & $\begin{array}{l}\text { İnfografikte kullanılması gereken bilgilerin tamamına sahip } \\
\text { olma durumu gözden geçirilir, varsa eksik bilgiler için kapsamlı } \\
\text { araştırma sürdürülür. }\end{array}$ \\
\hline
\end{tabular}




\begin{tabular}{|c|c|c|}
\hline & $\begin{array}{l}\text { Bilgiler, hangi sembolleri } \\
\text { akla getirmektedir? }\end{array}$ & $\begin{array}{l}\text { Simgeler, grafikler, şekiller, görüntüler, grafikler, benzetmeler, } \\
\text { vb. gibi görsel ipuçlarını kullanarak paralel bir yol çizmek bir } \\
\text { infografik fikri geliştirmenin etkili bir yoludur. }\end{array}$ \\
\hline \multirow{2}{*}{$\begin{array}{l}\text { NE } \\
\text { ZAMAN? }\end{array}$} & $\begin{array}{l}\text { Bilgiler konuyla ne } \\
\text { zaman ilgilidir? }\end{array}$ & $\begin{array}{l}\text { Bir infografiğin temelini oluşturan bilgiler zamana karşı duyarlı } \\
\text { olabilir (istatistiksel verilere dayanan görsellerin bir son } \\
\text { kullanma tarihi olabilir). }\end{array}$ \\
\hline & $\begin{array}{l}\text { Bilgilerin ne zaman } \\
\text { yayınlanması } \\
\text { gerekmektedir? }\end{array}$ & $\begin{array}{l}\text { İnfografik yayınlama zaman çizelgesi, hangi fikirlerin/bilgilerin } \\
\text { dikkate alınması gerektiğini ve hangilerinin bir kenara } \\
\text { bırakılması/geciktirilmesi gerektiği hakkında belirleyicidir. }\end{array}$ \\
\hline \multirow[t]{2}{*}{ NEREDE? } & $\begin{array}{l}\text { Veriler nereden } \\
\text { gelmektedir? }\end{array}$ & $\begin{array}{l}\text { İçerik bütünlüğünü korumak ve hedef kitleyi ilgilendiren ilgili } \\
\text { ve anlamlı bilgiler sunmaya devam etmek için, girdilerin } \\
\text { kaynağına dikkat etmek önemlidir. }\end{array}$ \\
\hline & $\begin{array}{l}\text { İnfografik nerede } \\
\text { yayınlanmaktadır? }\end{array}$ & $\begin{array}{l}\text { Yayın için hedeflenen kanalın ve hedef kitlenin beklentileri ile } \\
\text { yayı̈n parametrelerini göz önünde bulundurmak, üzerinde } \\
\text { çalışlan her görsel için fikirlerin ve bilgilerin filtrelenmesine } \\
\text { yardımcı olur. }\end{array}$ \\
\hline NEDEN? & $\begin{array}{l}\text { Bilgiler, hedef kitle için } \\
\text { neden önemlidir? }\end{array}$ & $\begin{array}{l}\text { Görselleştirilen bilgilerin çalışanlar, potansiyel müşteriler/ } \\
\text { müşteriler için neden önemli olduğu bilinmiyorsa, yeni bir fikre } \\
\text { geçmenin zamanı gelmiştir. }\end{array}$ \\
\hline NASIL? & $\begin{array}{l}\text { Bilgileri anlamak ne } \\
\text { kadar kolaydır? }\end{array}$ & $\begin{array}{l}\text { İnfografiğin amaçlanan mesajı net bir biçimde ilettiğinden emin } \\
\text { olmak gerekir. Mesaj, başkaları tarafından tam olarak } \\
\text { anlaşılmamışsa çizim tahtasına yeniden dönülür. }\end{array}$ \\
\hline
\end{tabular}

Tablo 3’te de görüldüğü gibi, infografik tasarım sürecinde kim, ne, ne zaman, nerede, neden ve nasıl aşamalarına ilişkin yanıtlanması gereken sorular ve ilgili açıklamalar yer almaktadır. Smiciklas (2012) tarafından ifade edilen ve tabloda yer alan her bir sorunun yanıtlanması ile başarılı bir infografik tasarımı gerçekleştirmenin mümkün olduğu söylenebilmektedir.

\section{1. İnfografiklerin Öğrenme Süreçlerinde Kullanılması}

Günümüzde, bireyler büyük miktarda veri ve bilgi ile karşı karşıya durumdadır. Haberler, reklamlar, e-postalar, sohbetler, kısa mesajlar, tweetler, kitaplar, reklam panoları, işaretler, vb. pek çok bilgiye odaklanmak, gereksiz olanları filtrelemek ve önemli şeyleri hatırlamak kullanıcılar için aşırı bir yük haline gelmektedir (Krum, 2014, s. 8). Söz konusu aşırı bilgi yükü ve kısalmış dikkat süresi çağında, pek çok kurum ve/veya kuruluş, iç ve dış paydaşlarına hızlı bilgi ve anlayış sağlama amacıyla infografiklerden yararlanmaktadır (Smiciklas, 2012, s. 6). Ayrıca, infografiklerin dijital çağda bilgi aktarımı için en etkili içerik biçimlerinden biri haline geldiğini söylemek mümkündür. Ayrıca, bilgilerin görselleştirilmesiyle öğrenmenin de geliştirilebildiğini ifade eden Smiciklas'a (2012, s. 11) göre infografik ile öğrenmenin avantajlarından bazıları şu şekilde sıralanabilmektedir:

- Bilgi, fikir ve kavramların daha iyi anlaşılmasına katkıda bulunur, 
- Eleştirel düşünme, fikir geliştirme ve düzenleme becerisini sağlar,

- Geliştirilmiş bilgi saklama ve hatırlama olanağı sunar.

Benzer şekilde, en uygun infografiğin, grafiklerden çok makale veya konuşmalara benzediğini ve bir öyküye sahip olduğunu ifade eden Krum (2014, s. 6), üç temel amaca odaklanmaktadır: (1) izleyiciyi bilgilendirmek, (2) eğlendirmek veya (3) ikna etmek. Bu bağlamda, Krum (2014), bir infografiğin okuyucunun dikkatini çekmek için amaciyla hazırlanmış bir tanıtım metninden (introduction) oluştuğunu ve bu sayede infografiği okumak için okuyucuların neden zaman ayırmaları gerektiğini öngörebildiklerini ifade etmektedir. Ayrıca, söz konusu infografiğin harekete geçirici bir sonuç mesajına sahip olması da, okuyucuların az önce öğrendikleri bilgilerle ne yapmaları gerektiğine dair göstergeler sunması bakımından son derece önemlidir. Ek olarak, Lamb ve Johnson (2014, s. 57), infografiklerin ve öğrenme süreçlerinde kullanılması amaçlarına ilişkin görüşlerini şu şekilde siralamaktadirlar:

- Fikirleri organize etmek,

- Karmaş1k ilişkileri göstermek,

- Bilgileri karşılaştırmak,

- Verileri anlamlı hale getirmek,

- Bir hikâye anlatmak.

Yukarıda sıralanan özelliklere ek olarak Çaka $(2018$, s. 6) da, öğrenmeyi destekleme ve etkili öğrenme çevrelerinin oluşturulması amacıyla infografiklerden yararlanılabileceğinin altını çizmektedir. Dahası, infografik gibi görsel temelli öğretim materyallerinde içerik ile ilişkili görsel öge kullanımının, hatırlama üzerinde olumlu bir etkisi olduğunu söylemek de olanaklıdır (Çaka, 2018, s. 8). Tüm bu özellikler nedeniyle, Alrwele (2017) infografiklerin öğrenme için umut verici bir teknik olabileceğini ve çeşitli öğrenme amaçlarına hizmet etmek üzere kullanılabileceğini dile getirmektedir.

Sonuç olarak, Krum (2014, s. 54), birkaç y1l içinde popülaritesini artıran infografiklerin, formatlarını yeni medya türlerine de dönüşerek büyümelerini sürdüreceğini ifade etmektedir. Bununla birlikte, internet kullanıcılarının ve okuyucuların filtrelemek ve anlamak zorunda oldukları veri miktarının da büyümeye devam edeceği bilinmektedir. $\mathrm{Bu}$ 
nedenle, Krum (2014), infografik tasarımların, öğrenilen bilgileri paylaşmak ve iletmek için gelecekte de en iyi araçlardan/ortamlardan biri olacağını savunmaktadır.

\subsection{Dijital Yerliler ve İnfografik}

Thomas (2011, s. 7), dünya çapında yükseköğrenim sürdüren öğrenen sayısındaki çarpıcı artışın arka planında, öğrenme süreçlerine ilişsin yeni yolları keşfetme gereksinimini de beraberinde getirdiğini vurgulamaktadır. Yeni dijital teknolojilerin varlığı, öğrenenlerin doğası ve öğrenme biçimleri hakkında değişen varsayımlar, dijital yerlilerin iletişim ve öğrenme gereksinimlerinin karşılanması konusunda farklı yolların denenmesi gerekliliğini gündeme getirmektedir. Diğer yandan, Gates Vakfi tarafindan 2006 yılında yayınlanan raporda, her on öğrenciden yedisinin motive olamamaları gerekçesiyle ders bıraktıkları ve ders bırakanların neredeyse yarısının ilgili dersleri sıkıcı buldukları ya da yeterince ilginç bulamadıkları bilinmektedir (Tapscott, 2009). Bu durumla ilgili olarak Tapscott (2009), dijital yerlilerin sessizce oturup ögretmen dersi dinlemekten memnun olmadıkları yönünde görüşlerini ifade etmektedir. Dijital olarak büyüyen neslin, öğrenme sürecine ilişkin ne öğrendikleri ne zaman öğrendikleri, bu öğrenmenin nerede ve nasıl gerçekleştiği konusunda bir seçim yapmada aktif rol almak istediklerini ifade etmek mümkündür. Dahası, öğrenme deneyimlerinin içinde yaşadıkları gerçek dünyayla ilgili olmasını, ilginç ve hatta eğlenceli olmasını istedikleri de açıktır (Tapscott, 2009).

Çalışma kapsamında, daha önceki başlıklar altında da ifade edildiği gibi, dijital yerliler günümüzde grafikler, şekiller, diyagramlar, vb. görsellerle dolu bir dünyada yaşamlarını sürdürmektedirler. Öğrenme alışkanlıkları ebeveynlerinden farklılık gösteren (Helsper \& Eynon, 2010; Prensky, 2001b), yavaş tempolu ortamlarda kolaylıkla sıkılabilen (Thompson, 2013), hız, yenilik, özgürlük, vb. yanısıra öğrenmede metin yerine grafikleri tercih eden (Tapscott, 2009) dijital yerlilerin öğrenme süreçlerinde infografiklerden yararlanılması etkili bir yöntem olarak düşünülebilir. Karmaşık fikirleri görsel olarak iletmenin en verimli yolu haline gelen infografikler, öğrenenlerin anlaşılması zor bir fikri görselleştirmelerine grafiksel bir temsili olarak katk1 sağlayabilir (Lamb \& Johnson, 2014, s. 54). Bu yenilikçi görsellerin, dijital yerlilere yeni düşünme yollarını keşfetmelerinde bir sinerji oluşturmalarına yardımcı olabilir. 
Alanyazında, dijital yerlilerin öğrenme süreçlerinde infografiklerin kullanılmasına yönelik araştırmalar bulunmakla birlikte sayıları oldukça sınırlıdır. Alrwele (2017, s. 112) tarafından yürütülen bir araştırmanın sonucunda, infografiklerin öğrencilerin ders içeriğini öğrenmedeki başarılarını iyileştirmede etkili olduğuna ilişkin bulgulara ulaşılmıştır. Ayrıca, öğrenenlerin, yaşam becerileri, duygusal ve entelektüel gelişimini geliştirmek amacıyla öğrenme sürecinde önemli bir potansiyele sahip olduğu da ilgili araştırmanın bulgularında ifade edilmektedir. İlgili araştırma sonuçları kapsamında, ağırlıklı olarak yazılı metin ve sözlü olarak sunulan materyaller kullanılarak yürütülen öğrenme süreçlerinde, karmaşık veya soyut kavramların öğrenilmesinde infografiklerin alternatif bir öğrenme aracı olarak sunulmasının öğrenme etkinliklerini desteklemesi bakımından önemli olduğu belirtilmiştir (Alrwele, 2017).

Benzer şekilde, Yıldırım ve Perdahçı (2019) tarafından yürütülen bir başka araştırmada ise interaktif infografiklerin, geleneksel öğrenme yönteminin kullanıldığ1 ortamlara göre derse karşı başarı tutum ve motivasyonu artırmada daha etkili olduğu sonucuna ulaşılmıştır. Pazilah ve Hashim (2018) ise dijital yerlilerin anlamlı öğrenme etkinliklerini desteklemede yeni teknolojileri içeren öğrenme stratejilerine gereksinim duyulduğunu belirtmektedirler. $\mathrm{Bu}$ kapsamda, öğrenme süreçlerinde infografiklerin kullanılmasının, dijital yerlilerin motivasyonlarını artıracağı ve öğrenmelerini olumlu yönde destekleyeceği düşünülmektedir.

\section{YÖNTEM}

\subsection{Araştırma Modeli}

$\mathrm{Bu}$ araştırmada, dijital yerlilerin öğrenme süreçlerinde infografiklerin nasıl kullanılabileceğine ilişkin önerilerin sunulduğu kuramsal bir çerçevenin geliştirilmesi amaçlanmıştır. $\mathrm{Bu}$ amaçla, "dijital yerlilerin ögrenme süreçlerinde infografikler nasıl kullanılabilir?" sorusu, araştırmanın ana sorusu olarak belirlenmiştir. Söz konusu araştırma, araştırmacının rolü üzerine kurulmuş veri toplama, verilerin çözümlenmesi ve yorumlanması süreçlerini içermesi (Creswell, 1994) ve nasıl sorusuna yanıt araması bakımından nitel bir bakış açısıyla desenlenmiştir. Araştırma modeli olarak ise çalışmanın kuramsal çerçevesini oluşturan dijital yerliler ile infografik kavramına ilişkin ulusal ve uluslararası alanyazın taraması gerçekleştirilmiş ve döküman incelemesi yöntemi tercih edilmiştir. 


\subsection{Veri Toplama Süreci}

Araştırma kapsamında, çalışmanın kuramsal çerçevesini oluşturan dijital yerliler ile infografik kavramına ilişkin ulusal ve uluslararası alanyazın taraması gerçekleştirmiştir. İlgili alanyazın taraması kapsamında, "dijital yerliler", "infografik", "dijital yerliler ve infografik" anahtar sözcükleri Türkçe ve İngilizce olarak aratılmıştır. İlgili aramalar, araştırmacıların erişimine açık olan üniversite kütüphaneleri tarafından erişim sağlanan dijital veri tabanlarında yapılmıştır. 2019 yılı Kasım ve 2020 yılı Ocak ayları arasında yapılan arama sonuçları kapsamında erişilen çalışmalardan, kitap, kitap bölümü, makale ve tezlerden oluşan toplam 34 (otuz dört) adet çalışma Ek olarak sunulmuştur. Söz konusu çalışmalar arasından, araştırma sorusu ile doğrudan ilgili olarak belirlenen çalışmalar konu, amaç ve kapsam açısından ayrıntılı olarak incelenmiş ve kuramsal bir çerçeve geliştirilmiştir.

$\mathrm{Bu}$ araştırma, araştırmacıların bağlı olduğu üniversite kütüphaneleri tarafından erişim sağlanan dijital veri tabanları ile bu veri tabanlarında 2019 yılı Kasım ve 2020 yılı Ocak ayları arasında yapılan arama sonuçları ve söz konusu arama sonuçları kapsamında erişilen araştırma sorusu ile doğrudan ilgili 34 (otuz dört) adet çalışma ile sınırlıdır.

\subsection{Verilerin Çözümü ve Yorumlanması}

Dökuman incelemesi kapsamında erişilen ve araştırma sorusu ile doğrudan ilgili kitap, kitap bölümü, makale ve tezlerden oluşan toplam 34 (otuz dört) adet çalışma, verilerin çözümü ve yorumlanması süreci bakımından ayrıntılı olarak incelenmiştir. Konu, amaç ve kapsam açısından incelenen çalışmalardan dijital yerlilerin öğrenme süreçlerinde infografiklerin nasıl kullanılabiliceğine ilişkin açıklamalar kuramsal çerçeve aracılığıyla sunulmuştur. Kuramsal çerçevenin geliştirilmesi sürecinde, Smiciklas (2012) tarafindan infografik kavramının üstün yönlerini ifade etmede kullanılan (1) özlük, (2) kavrama, (3) eylem ve (4) katılım ilkeleri ile Tapscott (2009) tarafından tanımlanan, dijital yerlilerin özelliklerini oluşturan: (1) özgürlük, (2) kişiselleştirme, (3) inceleme, (4) bütünlük, (5) işbirliği, (6) eğlence, (7) hız ve (8) yenilik özellikleri öncelikli olarak kategorize edilmiştir. İnfografik tasarımına ilişkin her bir ilke ile dijital yerli özellikleri eşleştirilmesinde yukarıda sözü edilen 34 (otuz dört) farklı araştırmanın bulgu ve sonuçları doğrultusunda yapılan çıkarımlardan yararlanılmıştır. Böylelikle, çalışmanın temel amacı olan dijital yerlilerin ögrenme süreçlerinde infografiklerin kullanımına ilişkin kuramsal çerçeve geliştirilmiştir. 
Araştırmanın inanırlığına katkı sağlamak üzere, söz konusu kuramsal çerçeve üç nitel uzmanı tarafından karşılaştırılmış ve doğrulaması yapılmıştır.

\section{BULGULAR ve YORUM}

$\mathrm{Bu}$ araştırmada, dijital dünya ile kuşatılmış olarak büyüyen bir nesil olan dijital yerlilerin öğrenme süreçlerinde, görsel iletişim arac1 olarak infografiklerin nasıl kullanılabileceğine ilişkin kuramsal bir çerçevenin geliştirilmesi amaçlanmıştır. Bu bağlamda, araştırmada geliştirilen kuramsal çerçevenin dayanağını Tapscott (2009) tarafından tanımlanan, dijital yerlilerin özelliklerini oluşturan: (1) özgürlük, (2) kişiselleştirme, (3) inceleme, (4) bütünlük, (5) işbirliği, (6) eğlence, (7) hız ve (8) yenilik ile Smiciklas (2012) tarafindan infografik kavramının üstün yönlerini ifade etmede kullanılan (1) özlük, (2) kavrama, (3) eylem ve (4) katılım ilkeleri oluşturmaktadır. Araştırma kapsamında geliştirilen kuramsal çerçeve Tablo 4'te sunulmuştur:

Tablo 4. Dijital yerlilerin öğrenme süreçlerinde infografiklerin kullanımına ilişkin kuramsal çerçeve

Görsel Bir İletişim Aracı Olarak Infografikler (Smiciklas, 2012)
Dijital Yerlilerin

Özellikleri

(Tapscott, 2009)
AÇIKLAMALAR

\begin{tabular}{|c|c|c|}
\hline ÖZLÜK & Hiz & $\begin{array}{l}\text { - Hedef kitlenin özelliklerinin bilinmesi, } \\
\text { - İnfografikte yer alan bilgilerin özlü olması, } \\
\text { - Bilgilerin, hedef kitlenin gereksinimlerini karşılaması, } \\
\text { - Bilgilerin hedef kitlenin hızına uygun olarak tasarlanması. }\end{array}$ \\
\hline KAVRAMA & Bütünlük & 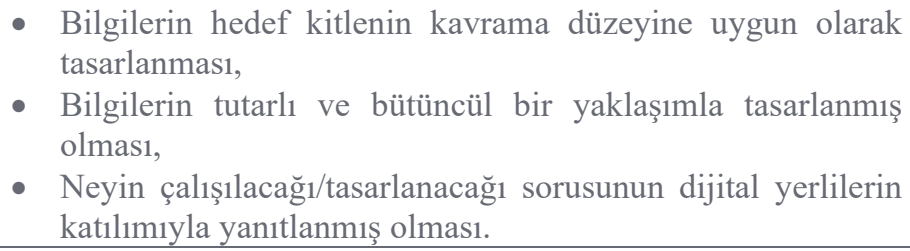 \\
\hline EYLEM & Eğlence & $\begin{array}{l}\text { - İnfografiğin, hedef kitlenin eğlence anlayışına uygun olarak } \\
\text { tasarlanması, } \\
\text { - Gösterilen çaba için anında geribildirim ve kazanç } \\
\text { beklentisinin karşılanmış olması, } \\
\text { - Öğrenme motivasyonunu artırmada kurgu/hayal gücü } \\
\text { bağlamının bulunması. }\end{array}$ \\
\hline
\end{tabular}




\begin{tabular}{|c|c|c|}
\hline & Yenilik & $\begin{array}{l}\text { - İnfografiğin, yeni fikirler, ortamlar ve teknolojiler için } \\
\text { harekete geçirmek üzere tasarlanmış olması, } \\
\text { - Öğrenme, çalışma ve eğlenme için yenilikçi bir yol/yöntem } \\
\text { sunulması. }\end{array}$ \\
\hline & İşbirliği & $\begin{array}{l}\text { - İnfografiğin, hedef kitlenin birbirleri ile olan işbirliğini } \\
\text { desteklemesi, } \\
\text { - İnfografiğin, hedef kitle arasında paylaşıma (yeni medya } \\
\text { ortamları, sosyal ağlar, vb.) uygun olması. }\end{array}$ \\
\hline \multirow{3}{*}{ KATILIM } & İnceleme & $\begin{array}{l}\text { - İnfografikte yer alan bilgi kaynaklarının paylaşımının şeffaf } \\
\text { olmasi, } \\
\text { - Hedef kitlenin, bilgilerin sorgulanabilmesi konusunda } \\
\text { cesaretlendirilmesi. }\end{array}$ \\
\hline & Kişiselleştirme & $\begin{array}{l}\text { - Üretilen bilgilerin, hedef kitle tarafından yeniden } \\
\text { kullanımına uygun olması, } \\
\text { - İnfografiğin, hedef kitlenin ilgisini çekmesi. }\end{array}$ \\
\hline & Özgürlük & $\begin{array}{l}\text { - İnfografiğin, hedef kitlenin düşüncelerini ifade etme, } \\
\text { problem çözme, vb. süreçlere aktif katılımlarını } \\
\text { desteklemesi. }\end{array}$ \\
\hline
\end{tabular}

Tablo 4'te yer alan, dijital yerlilerin öğrenme süreçlerinde infografiklerin kullanımına ilişkin kuramsal çerçeve kapsamında, araştırma bulgularını (1) özlük, (2) kavrama, (3) eylem ve (4) katılım olmak üzere dört grupta kategorize etmek mümkündür.

Smiciklas (2012), infografikler özlü yapılar olduğunu ve bir kitlenin büyük miktardaki veriyi hızlı bir şekilde anlamasına katkıda bulunduğunu ifade etmiştir. Tapscott (2009) ise $h ı z$ özelliği ile ilgili olarak, dijital yerlilerin yalnızca video oyunlarında değil, yaşamlarının her anında hıza gereksinim duyduklarını, hızın, bilgi akışını biçimlendirdiği bir dünyada, bilgiye çok hızlı bir biçimde erişmeye alışkın olan dijital yerlilerin (Helsper \& Eynon, 2010), mesajlarına da aynı hızda yanıt almak istediklerini ifade etmiştir. Dolayısıyla, özlük ilkesine ilişkin olarak, hedef kitlenin özelliklerinin bilinmesi, hedef kitlenin özellikleri doğrultusunda hızlarına ve beklentilerine yönelik tasarımlar (Sarkar, Ford, \& Manzo, 2017) gerçekleştirilmesi ve bilgilerin öz bir biçimde sunulması yönünde bulgulara ulaşılmıştır.

Kavrama ilkesine ilişkin bulgular, dijital yerlilerin bütünlük özelliği ile açıklanmaktadır (Smiciklas, 2012; Tapscott, 2009). Bu çerçevede, infografiklerde yer alan bilgilerin hedef kitlenin kavrama düzeyine uygun bir biçimde, tutarlı ve bütüncül bir yaklaşımla tasarlanması, neyin çalışılacağı ve/veya tasarlanacağı sorusunun, dijital yerlilerin katılımıyla yanıtlanması gerektiği söylenebilir.

Eylem ilkesini, Smiciklas (2012) bireyler üzerinde infografiklerin hızlı karar verebilme ve harekete geçebilme konusunda etkili olduğu yönünde tanımlamıştır. Benzer şekilde, 
Tapscott (2009) ise dijital yerlilerin eğlence özelliğini, işyerinde, eğitimde ve sosyal yaşamlarında eğlence (Downes \& Bishop, 2012) ve oyun odaklı olmaları ile açıklamaktadır. $\mathrm{Bu}$ bağlamda, eylem ilkesi açısından ele alındığında, eğlence özelliğine ilişkin bulgular, infografiklerin hedef kitlenin eğlence anlayışına uygun olarak tasarlanması, öğrenme sürecinde motivasyonun artırılmasında kurgu/hayal gücü ürünlerinden yararlanılması (Thompson, 2013) olarak belirtilebilir. Ayrıca, dijital yerlilerin, günlük yaşamlarında gösterdikleri her çaba için anında geribildirim ve kazanç beklentisinde bulunmaları göz önüne alındığında, infografiklerin bu beklentiyi karşılamaya yönelik tasarımlar/süreçler içermesi gerektiği ifade edilebilmektedir. Yenilik özelliği ile ilgili olarak ise Tapscott (2009), yeni teknolojileri tercih etme eğiliminde olduklarını, çalışabilecekleri yenilikçi şirketler, kurum ve/veya kuruluşlar aramak, işbirliği yapmak, öğrenmek, çalışmak ve kendilerini eğlendirmek için yenilikçi yollar denediklerini de eklemektedir. Dolayısıyla, eylem ilkesi kapsamında, yenilik özelliği ile ilgili olarak, infografiklerin yeni fikirler, ortamlar ve teknolojiler için dijital yerlileri harekete geçirmek üzere tasarlanması, öğrenme, çalışma ve eğlenme için yenilikçi bir yol/yöntem sunması konusunda bulgulara ulaşılmıştır. İşbirliği özelliği Tapscott (2009) tarafından, dijital yerlilerin, işbirliği ve ilişki odaklı olması ile tanımlanmaktadır. Dijital yerliler sosyal ağlarda işbirliği yapabilmekte, çok kullanıcılı video oyunları oynayabilmekte ve birbirleri ile okul, iş veya yalnızca eğlence amaçlı veriler paylaşabilmektedirler. Aynı zamanda, ilişki odaklı da davranabilen dijital yerliler, bir ürünü satın almada, markaları, şirketleri, ürünleri ve hizmetleri tercih ederken birbirlerini etkileyebilmektedirler. Dolayısyla, öğrenme sürecinde kullanılan infografiklerin, hedef kitlenin birbirleri ile olan işbirliğini desteklemesi ve infografiklerin hedef kitle arasında paylaşıma olanak vermesi, işbirliği özelliğine ilişkin bulgular arasında yer almaktadır.

Katılım ilkesi ile ilgili olarak, Smiciklas (2012), bir kurum ve/veya kuruluşta çalışanların veri görselleştirmesi ile ilgisinin daha fazla çekilmesi ve ilgili çalışanların, düşüncelerini ifade etme, problem çözme vb. süreçlere aktif bir biçimde katılımlarının desteklendiğini ifade etmektedir. Tapscott (2009) ise inceleme özeliğine ilişkin, dijital yerliler için şeffaflığın son derece doğal algılandığı, dolayısıyla kurumlar, paydaşlar, şirketler, vb. hakkında ilgili bilgilere erişmede bir sakınca görmediklerini belirtmektedir. Bu bağlamda, öğrenme sürecinde kullanılacak olan infografiklerde yer alan bilgi kaynaklarının dijital yerlilerle şeffaf bir anlayışla paylaşılması ve söz konusu bilgileri sorgulayabilmeleri 
konusunda cesaretlendirilmeleri gerektiği ilgili bulgular arasında gösterilebilmektedir. Kişiselleştirme özelliği ile ilgili olarak, dijital yerlilerin, çevrelerindeki medya dünyasını (masaüstü, web sitesi, zil sesi, tanıtıc1, ekran koruyucu, haber kaynakları, eğlence, vb.) değiştirebildikleri bilinmektedir (Tapscott, 2009). Bu doğrultuda, öğrenme ortamında kullanılmak üzere bilgilerin ve/veya tasarımların dijital yerliler tarafindan değiştirilmesine, kişiselleştirilmesine ve hatta yeniden kullanılmasına yönelik üretilmesi gerektiği bulgular arasındadır. Son olarak, dijital yerlilerin karşılaştıkları durumlarla ilgili, teknolojiden de yararlanarak, seçim yapabilme özgürlüğüne sahip olmak istedikleri bilinmektedir (Tapscott, 2009). Bu bağlamda, özgürlük özelliğine ilişkin bulgu olarak, öğrenme sürecinde kullanılacak bilgilerin, dijital yerlilerin düşüncelerini ifade etme, problem çözme, vb. süreçlere aktif katılımlarını (Sarkar, Ford, \& Manzo, 2017) desteklemesi gerektiği yer almaktadır.

\section{SONUÇ ve ÖNERILER}

Dijital yerlilerin öğrenme süreçlerinde, görsel iletişim aracı olarak infografiklerin nasıl kullanılabileceği sorusuna yanıt aranan bu araştırmada, dijital yerliler ve infografik konularında araştırma yapmak isteyen kurum/kuruluşlara, araştırmacılara ve öğrenenlere yol gösterici nitelikte olduğu düşünülen kuramsal bir çerçeve geliştirilmiştir. Buckingham (2011), toplumsal değişimin karmaşık, dengesiz doğasını ve bunun içinde teknolojinin yerini anlamak için daha ölçülü ve dikkatli araştırmalara gereksinim duyulduğunu ifade etmektedir. Dolayısıyla, dijital yerli tanımı çerçevesinde alanyazında yer alan eleştiriler düşünüldügünde, bu araştırmanın ilgili alanyazının geliştirilmesine katkı sunduğunu da ifade etmek mümkündür.

Son olarak, Margaryan, Littlejohn ve Vojt (2011, s. 439) tarafından da ifade edildiği gibi benzer konunun farklı teknolojilerle ve farklı gruplarla geniş kapsamda çalışılması ilgili alanyazının gelişimine katkı sağlayabilir. Ayrıca, alanyazında dijital yerlilere ilişkin eleştirilerden biri olarak ampirik çalışmaların sayıca azlığı göz önünde bulundurulduğunda, önerilen kuramsal çerçevenin uygulamaya dönük bir araştırmaya dönüştürülmesi, gelecekte yapılacak çalışmalar için bir öneri olarak sunulabilir.

\section{EXTENDED ABSTRACT}


The concept of digital natives (Kirschner \& Bruyckere, 2017; Ng, 2012), first introduced in 2001 by Marc Prensky, is used to describe individuals (Prensky, 2001a) who were born in the 1990s and are the digital natives of the language of computers, video games, and the Internet. Digital natives who spend a significant part of their daily lives on the screen (Tapscott, 2009, p. 3) or online believe that the Internet is a natural component of their lives (Dingli \& Seychell, 2015, p. 9). Digital natives with the ability of multitasking in parallel processes (Prensky, 2001a; Palfrey \& Gasser, 2008; Tapscott, 2009; Kirschner \& Merrie nboer, 2013), differ from past generations in aspects such as communication, learning, socialization, etc. (Helsper \& Eynon, 2010; Prensky, 2001b; Palfrey \& Gasser, 2008).

Digital natives who live in a world full of visuals such as graphics, shapes, diagrams, etc. today, can easily get bored in slow-paced environments and lose their interest and motivation about learning when they are exposed to intense digital data flow (Thompson, 2013). Similarly, Tapscott (2009) stated that according to a report published by the Gates Foundation in 2006, seven out of ten students drop out from courses that they could not be motivated, and that almost half of those who dropped the classes either found boring or did not find interesting enough. This shows that digital natives want their learning experiences to be related to the real world they live in, to be interesting, and even fun. In this context, besides the features such as speed, innovation, freedom, etc. in the use of infographics in the learning processes of digital natives, who prefer graphics instead of text, could be considered as an effective method (Tapscott, 2009; Thompson, 2013). Infographics defined as a visual representation of their complex data (Krum, 2014, p. 6) are shown as a promising technique (Alrwele, 2017, p. 105) for use in learning processes. At the same time, infographics (Smiciklas, 2012, p. 11), expressed as one of the most productive content formats for the transfer of information in the digital age can contribute to the learning processes in conducting an effective communication with the digital natives (Yuvaraj, 2017, p. 9).

This study aims to develop a theoretical framework to suggest how infographics could be used in digital natives' learning processes. For this purpose, the main question of the research is set as "how infographics can be used in digital natives' learning processes?". This study was designed with qualitative research perspective, the document analysis method was preferred as the research model. In this context, a theoretical framework has been developed on the use of infographics in the learning processes of digital natives, through the research 
reached by review of the literature in Turkish and English. The literature researches were made in electronic databases accessible by university libraries, which are accessible to researchers. A total of 34 (thirty-four) papers, consisted of books, book chapters, articles, and dissertations, which were accessed between November 2019 and January 2020, directly related to the research question. Therefore, the research is limited by 34 (thirty-four) academic papers, accessed between November 2019 and January 2020 gathered from electronic databases of the universities of the researchers.

A total of 34 (thirty-four) academic papers consisted of books, book chapters, articles, and dissertations directly accessed within the scope of the document review were examined in detail in terms of the analysis and interpretation of the data. With the completion of the analysis and interpretation of the data, a theoretical framework has emerged regarding the use of infographics in the learning processes of digital natives. To contribute to the credibility of the research, the theoretical framework is compared and verified by three experts on qualitative research.

In this context, the findings regarding the theoretical basis of the study is constituted of Tapscott's (2009) eight norms of digital natives which form the characteristics of the generation: (1) freedom, (2) corporate integrity, (3) openness, (4) entertainment, (5) play, (6) collaboration, (7) relationship, (8) speed and, Smiciklas' (2012) four benefits of data visualization: (1) brevity, (2) insight, (3) action and, (4) engagement explaining the strengths of infographics. In this research, a theoretical framework is developed to answer the question of how to use infographics as a visual communication tool in the learning processes of digital natives, to guide the institutions/organizations, researchers, and learners who are interested in research on digital natives and infographics. Buckingham (2011) states that more measured and careful research is needed to understand the complex, unstable nature of social change and the place of technology in society. Therefore, considering the criticisms in the literature within the context of digital native definition, it is possible to state that this research contributes to the development of the related literature.

Finally, as stated by Margaryan, Littlejohn and Vojt (2011, p. 439), similar subject with different technologies and different working groups in a wide range of research can contribute to the development of the related literature. In addition, considering the low number of empirical studies made on digital natives is one of the criticisms in the literature, 
applying the proposed theoretical framework into a practical research is offered as a suggestion for future studies.

\section{KAYNAKÇA}

Alrwele, N. S. (2017). Effects of infographics on student achievement and students' perceptions of the impacts of infographics. Journal of Education and Human Development , 6 (3), 104-117.

Bennett, S., Maton, K. A., \& Kervin, L. (2008). The 'digital natives' debate: A critical review of the evidence. British Journal of Educational Technology , 39 (5), 775-786.

Buckingham, D. (2011). Foreword. M. Thomas içinde, Deconstructing digital natives: Young people, technology and the new literacies (s. ix-xi). New York: Routledge.

Creswell, J. W. (1994). Research design: Qualitative and quantitative approaches. Hershey: PA: Sage Publications.

Çaka, C. (2018). Farklı infografik tasarımlarının öğrenme çıktılarına, bilişsel yüke ve motivasyona etkisi. Yayımlanmamış Doktora Tezi. Eskişehir: Anadolu Üniversitesi, Eğitim Bilimleri Enstitüsü.

Çaydere, O. (2016). Grafik Tasarım Eğitiminde Temel Tasarım Eğitiminin Önemi. Fine Arts (NWSAFA), 11(2), 93-97.

Dingli, A., \& Seychell, D. (2015). The new digital natives cutting the chord. Berlin: Springer.

Downes, J. M., \& Bishop, P. (2012). Educators engage digital natives and learn from their experiences with technology. Middle School Journal, 43(5), 6-15.

Dyjur, P., \& Li, L. (2015). Learning 21st century skills by engaging in an infographics assignment. B. Preciado, Takeuchi, \& Lock içinde, IDEAS: Designing Responsive Pedagogy (s. 62-71). Werklund School of the Education, University of Calgary.

Frascara, J. (2004). Communication Design: Principles, Methods, and Practice. New York: Allworth Press.

Halloway, S. L., \& Valentine, G. (2002). Cyberkids? Exploring childrens's identities and social networks in on-line and off-line worlds. annals of the Association of American Geographers , 92 (2), 302-319.

Helsper, E. J., \& Eynon, R. (2010). Digital natives: Where is the evidence? British Educational Research Journal , 36 (3), 503-520. 
Howe, N., \& Strauss, W. (2000). Millennials rising: The next generations. New York: Vintage Books.

Jones, C. (2011). Students the net generation, and digital natives: Accounting for educational change. M. Thomas içinde, Deconstructing digital natives: Young people, technology and the new literacies (s. 30-48). New York: Routledge.

Kirschner, P. A., \& Bruyckere, P. D. (2017). The myths of the digital native and the multitasker. Teaching and Teacher Education , 67 (2017), 135-142.

Kirschner, P. A., \& Merrie n̈boer, J. G. (2013). Do learners really know best? Urban legends in education. Educational Psychologist , 48 (3), 169-183.

Krum, R. (2014). Cool infographics: Effective communication with data visualization and design. Indiana: Wiley.

Lamb, A., \& Johnson, L. (2014). Infographics part 1: Invitations to Inquiry. Teacher Librarian , 15 (2), 54-58.

Leppisaari, I., \& Lee, O. (2012). Modelling digital natives' international collaboration: Finnish-Korean experiences of environmental education. Educational Technology \& Society, 15 (2), 244-256.

Levy, R. (2011). Young children, digital technology, and interaction with text. M. Thomas içinde, Deconstructing digital natives: young people, technology and the new literacies (s. 151-166). New York: Routledge.

Margaryan, A., Littlejohn, A., \& Vojt, G. (2011). Are digital natives a myth or reality? University students' use of digital technologies. Computers \& Education, 56 (2), 429-440.

Ng, W. (2012). Can we teach digital natives digital literacy? Computers \& Education, 59 (3), 1065-1078.

Nuhoğlu-Kibar, P., \& Akkoyunlu, B. (2018). Ortaokul düzeyinde öğrenme stratejisi olarak infografik oluşturma sürecinin eğitsel tasarım araştırması yöntemiyle modellenmesi. Eğitim ve Bilim , 43 (196), 97-123.

Palfrey, J., \& Gasser, U. (2008). Born digital: Understanding the first generation of the digital natives. New York: Basic Books.

Pazilah, F. N., \& Hashim, H. (2018). Using infographics as a technology-based tool to develop 21st century skills in an ESL context. Journal of Educational and Learning Studies , 1 (1), 35-38.

Prensky, M. (2001a). Digital natives, digital immigrants. On the Horizon, 9 (5), 1-6.

Prensky, M. (2001b). Digital natives, digital immigrants, Part II: Do they really think differently? On the Horizon, 9 (6), 1-6. 
Prensky, M. (2011). Gidital wisdom and homo sapiens digital. M. Thomas içinde, Deconstructing digital natives: Young people, technology and the new literacies (s. 15-29). New York: Routledge.

Sarkar, N., Ford, W., \& Manzo, C. (2017). Engaging digital natives through social learning. Systemics, Cybernetics and Informatics, 15(2), 1-4.

Smiciklas, M. (2012). The powerof infographics: Using pictures to communicate and connect with your audiences. Indiana: Que.

Smith, E. E. (2012). The digital native debate in higher education: A comparative analysis of literature. Canadian Journal of Learning and Technology, 38 (3), 1-18.

Tapscott, D. (2009). Grown up digital: How the net generation is changing your world. New York: McGraw-Hill.

Thomas, M. (2011). Technology, education, and the discourse of the digital native: Between evangelists and dissenters. M. Thomas içinde, Deconstructing digital natives: Young people, technology and the new literacies (s. 1-14). New York: Routledge.

Thompson, P. (2013). The digital natives as learners: Technology use patterns and approaches to learning. Computers \& Education , 65 (2013), 12-33.

Williams, D. L., Crittenden, V. L., Keo, T., \& McCarty, P. (2012). The use of social media: An exploratory study of usage among digital natives. Journal of Public Affairs , 12 (2), 127-136.

Yıldırım, Y. S., \& Perdahçı, Z. N. (2019). Eğitimde interaktif infografik kullanımının öğrenci başar1, tutum ve motivasyonuna etkisi. The turkish Online Journal of Design, Art and Communication - TOJDAC , 9 (3), 449-463.

Yuvaraj, M. (2017). Infographics: Tools for designing, visualizing data and storytelling in libraries. Library Hi Tech News , 5, 6-9. 


\section{EK: KURAMSAL ÇERÇEVENIN OLUŞTURULMASI SÜRECINDE YARARLANILAN ARAŞTIRMALARIN LISTESİ}

1. Alrwele, N. S. (2017). Effects of infographics on student achievement and students' perceptions of the impacts of infographics. Journal of Education and Human Development , 6 (3), 104-117.

2. Bennett, S., Maton, K. A., \& Kervin, L. (2008). The 'digital natives' debate: a critical review of the evidence. British Journal of Educational Technology, 39 (5), 775-786.

3. Buckingham, D. (2011). Foreword. M. Thomas içinde, Deconstructing digital natives: young people, technology and the new literacies (s. ix-xi). New York: Routledge.

4. Çaka, C. (2018). Farklı infografik tasarımlarının öğrenme çıktılarına, bilişsel yüke ve motivasyona etkisi. Yayımlanmamış Doktora Tezi. Eskişehir: Anadolu Üniversitesi, Eğitim Bilimleri Enstitüsü.

5. Dingli, A., \& Seychell, D. (2015). The new digital natives cutting the chord. Berlin: Springer.

6. Downes, J. M., \& Bishop, P. (2012). Educators Engage Digital Natives and Learn from Their Experiences with Technology. Middle School Journal, 43(5), 6-15.

7. Dyjur, P., \& Li, L. (2015). Learning 21st century skills by engaging in an infographics assignment. B. Preciado, Takeuchi, \& Lock içinde, IDEAS: Designing Responsive Pedagogy (s. 62-71). Werklund School of the Education, University of Calgary.

8. Halloway, S. L., \& Valentine, G. (2002). Cyberkids? Exploring childrens's identities and social networks in on-line and off-line worlds. annals of the Association of American Geographers , 92 (2), 302-319.

9. Helsper, E. J., \& Eynon, R. (2010). Digital natives: where is the evidence? British Educational Research Journal , 36 (3), 503-520.

10. Howe, N., \& Strauss, W. (2000). Millennials rising: the next generations. New York: Vintage Books.

11. Jones, C. (2011). Students the net generation, and digital natives: accounting for educational change. M. Thomas içinde, Deconstructing digital natives: young people, technology and the new literacies (s. 30-48). New York: Routledge.

12. Kirschner, P. A., \& Bruyckere, P. D. (2017). The myths of the digital native and the multitasker. Teaching and Teacher Education, 67 (2017), 135-142.

13. Kirschner, P. A., \& Merrie n̈boer, J. G. (2013). Do learners really know best? Urban legends in education. Educational Psychologist , 48 (3), 169-183. 
14. Krum, R. (2014). Cool infographics: effective communication with data visualization and design. Indiana: Wiley.

15. Lamb, A., \& Johnson, L. (2014). Infographics part 1: Invitations to Inquiry. Teacher Librarian, 15 (2), 54-58.

16. Leppisaari, I., \& Lee, O. (2012). Modelling digital natives' international collaboration: Finnish-Korean experiences of environmental education. Educational Technology \& Society, 15 (2), 244-256.

17. Levy, R. (2011). Young children, digital technology, and interaction with text. M. Thomas içinde, Deconstructing digital natives: young people, technology and the new literacies (s. 151-166). New York: Routledge.

18. Margaryan, A., Littlejohn, A., \& Vojt, G. (2011). Are digital natives a myth or reality? University students' use of digital technologies. Computers \& Education, 56 (2), 429 440.

19. Ng, W. (2012). Can we teach digital natives didgital literacy? Computers \& Education, 59 (3), 1065-1078.

20. Nuhoğlu-Kibar, P., \& Akkoyunlu, B. (2018). Ortaokul düzeyinde öğrenme stratejisi olarak infografik oluşturma sürecinin eğitsel tasarım araştırması yöntemiyle modellenmesi. Ĕgitim ve Bilim , 43 (196), 97-123.

21. Palfrey, J., \& Gasser, U. (2008). Born digital: understanding the first generation of the digital natives. New York: Basic Books.

22. Pazilah, F. N., \& Hashim, H. (2018). Using infographics as a technology-based tool to develop 21 st century skills in an ESL context. Journal of Educational and Learning Studies , 1 (1), 35-38.

23. Prensky, M. (2001a). Digital natives, digital immigrants. On the Horizon, 9 (5), 1-6.

24. Prensky, M. (2001b). Digital natives, digital immigrants, Part II: Do they really think differently? On the Horizon , 9 (6), 1-6.

25. Prensky, M. (2011). Gidital wisdom and homo sapiens digital. M. Thomas içinde, Deconstructing digital natives: young people, technology and the new literacies (s. 15-29). New York: Routledge.

26. Sarkar, N., Ford, W., \& Manzo, C. (2017). Engaging Digital Natives Through Social Learning. Systemics, Cybernetics and Informatics, 15(2), 1-4.

27. Smiciklas, M. (2012). The powerof infographics: using pictures to communicate and connect with your audiences. Indiana: Que.

28. Smith, E. E. (2012). The digital native debate in higher education: a comparative analysis of literature. Canadian Journal of Learning and Technology, 38 (3), 1-18. 
29. Tapscott, D. (2009). Grown up digital: how the net generation is changing your world. New York: McGraw-Hill.

30. Thomas, M. (2011). Technology, education, and the discourse of the digital native: between evangelists and dissenters. M. Thomas içinde, Deconstructing digital natives: young people, technology and the new literacies (s. 1-14). New York: Routledge.

31. Thompson, P. (2013). The digital natives as learners: Technology use patterns and approaches to learning. Computers \& Education , 65 (2013), 12-33.

32. Williams, D. L., Crittenden, V. L., Keo, T., \& McCarty, P. (2012). The use of social media: an exploratory study of usage among digital natives. Journal of Public Affairs , 12 (2), 127-136.

33. Yıldırım, Y. S., \& Perdahçı, Z. N. (2019). Eğitimde interaktif infografik kullanımının ögrenci başarı, tutum ve motivasyonuna etkisi. The turkish Online Journal of Design, Art and Communication - TOJDAC , 9 (3), 449-463.

34. Yuvaraj, M. (2017). Infographics: tools for designing, visualizing data and storytelling in libraries. Library Hi Tech News , 5, 6-9. 